OPEN ACCESS

Edited by:

Manuel Kleiner,

University of Calgary, Canada

Reviewed by:

James Moir,

University of York, UK

Julio Perez,

Delft University of Technology,

Netherlands

${ }^{*}$ Correspondence: Lisa Y. Stein

lisa.stein@ualberta.ca

Specialty section:

This article was submitted to Microbial Physiology and Metabolism,

a section of the journal

Frontiers in Microbiology

Received: 24 May 2016

Accepted: 29 June 2016

Published: 12 July 2016

Citation:

Kozlowski JA, Kits KD and Stein LY (2016) Comparison of Nitrogen Oxide Metabolism among Diverse Ammonia-Oxidizing Bacteria.

Front. Microbiol. 7:1090. doi: 10.3389/fmicb.2016.01090

\section{Comparison of Nitrogen Oxide Metabolism among Diverse Ammonia-Oxidizing Bacteria}

\author{
Jessica A. Kozlowski, K. Dimitri Kits and Lisa Y. Stein* \\ Department of Biological Sciences, Biological Sciences Building, University of Alberta, Edmonton, AB, Canada
}

Ammonia-oxidizing bacteria $(\mathrm{AOB})$ have well characterized genes that encode and express nitrite reductases (NIR) and nitric oxide reductases (NOR). However, the connection between presence or absence of these and other genes for nitrogen transformations with the physiological production of nitric oxide (NO) and nitrous oxide $\left(\mathrm{N}_{2} \mathrm{O}\right)$ has not been tested across $A O B$ isolated from various trophic states, with diverse phylogeny, and with closed genomes. It is therefore unclear if genomic content for nitrogen oxide metabolism is predictive of net $\mathrm{N}_{2} \mathrm{O}$ production. Instantaneous microrespirometry experiments were utilized to measure $\mathrm{NO}$ and $\mathrm{N}_{2} \mathrm{O}$ emitted by $\mathrm{AOB}$ during active oxidation of ammonia $\left(\mathrm{NH}_{3}\right)$ or hydroxylamine $\left(\mathrm{NH}_{2} \mathrm{OH}\right)$ and through a period of anoxia. This data was used in concert with genomic content and phylogeny to assess whether taxonomic factors were predictive of nitrogen oxide metabolism. Results showed that two oligotrophic AOB strains lacking annotated NOR-encoding genes released large quantities of $\mathrm{NO}$ and produced $\mathrm{N}_{2} \mathrm{O}$ abiologically at the onset of anoxia following $\mathrm{NH}_{3}$-oxidation. Furthermore, high concentrations of $\mathrm{N}_{2} \mathrm{O}$ were measured during active $\mathrm{O}_{2}$-dependent $\mathrm{NH}_{2} \mathrm{OH}$ oxidation by the two oligotrophic $\mathrm{AOB}$ in contrast to non-oligotrophic strains that only produced $\mathrm{N}_{2} \mathrm{O}$ at the onset of anoxia. Therefore, complete nitrifier denitrification did not occur in the two oligotrophic strains, but did occur in meso- and eutrophic strains, even in Nitrosomonas communis Nm2 that lacks an annotated NIR-encoding gene. Regardless of mechanism, all AOB strains produced measureable $\mathrm{N}_{2} \mathrm{O}$ under tested conditions. This work further confirms that $\mathrm{AOB}$ require $\mathrm{NOR}$ activity to enzymatically reduce $\mathrm{NO}$ to $\mathrm{N}_{2} \mathrm{O}$ in the nitrifier denitrification pathway, and also that abiotic reactions play an important role in $\mathrm{N}_{2} \mathrm{O}$ formation, in oligotrophic AOB lacking NOR activity.

Keywords: nitrogen oxides, nitrifier denitrification, ammonia-oxidizers, Nitrosomonas, Nitrosospira, nitrous oxide, nitric oxide, chemodenitrification

\section{INTRODUCTION}

Chemolithotrophic ammonia-oxidizing bacteria $(\mathrm{AOB})$ are important players in the global biogeochemical nitrogen cycle and perform the first step in nitrification; the oxidation of ammonia $\left(\mathrm{NH}_{3}\right)$ to nitrite $\left(\mathrm{NO}_{2}^{-}\right)$. AOB are abundant in a vast array of environments including soils, marine and fresh-water, and wastewater treatment plants (Klotz et al., 2006; Norton et al., 2008; Jia and Conrad, 2009; Ke et al., 2015) and are implicated in production of nitrous oxide $\left(\mathrm{N}_{2} \mathrm{O}\right)$ through 
enzymatic (Stein, 2011; Kozlowski et al., 2014) and abiotic processes (Jones et al., 2015; Zhu-Barker et al., 2015). AOB have the potential to utilize $\mathrm{NO}_{2}^{-}$as an alternate terminal electron acceptor through the process of nitrifier denitrification (Stein, 2011) resulting in net production of $\mathrm{N}_{2} \mathrm{O}$ (Stein and Yung, 2003; Kool et al., 2011; Zhu et al., 2013). $\mathrm{N}_{2} \mathrm{O}$ has been measured from pure cultures of AOB from both the Nitrosomonas (Poth and Focht, 1985; Kozlowski et al., 2014) and Nitrosospira (Dundee and Hopkins, 2001; Wrage et al., 2004; Shaw et al., 2006) genera. However, studies on the enzymology and pathways of $\mathrm{N}_{2} \mathrm{O}$ production by AOB have mostly focused on $N$. europaea ATCC 19718 (Beaumont et al., 2002, 2004; Cantera and Stein, 2007; Yu and Chandran, 2010; Yu et al., 2010; Kozlowski et al., 2014) leaving open the possibility that not all AOB strains share equivalent pathways and regulatory mechanisms.

The nitrifier denitrification pathway includes a nitrite reductase (NIR) to reduce $\mathrm{NO}_{2}^{-}$to nitric oxide (NO) and nitric oxide reductase (NOR) to reduce $\mathrm{NO}$ to $\mathrm{N}_{2} \mathrm{O}$. All closed $\mathrm{AOB}$ genomes, with the exception of $N$. communis $\mathrm{Nm} 2$ (Kozlowski et al., 2016b), have genes encoding the copper-containing NirK (Prosser et al., 2014). Furthermore, all AOB encode NOR genes (norB and/or nor $Y$ ) with the exception of Nitrosomonas sp. Is79A3 (Bollmann et al., 2013) and N. ureae Nm10 (Kozlowski et al., 2016a). Both Nitrosomonas sp. Is79A3 and N. ureae $\mathrm{Nm} 10$ are considered oligotrophic, growing optimally in medium containing 1-5 mM ammonium (Prosser et al., 2014). In contrast, $N$. communis $\mathrm{Nm} 2$ is considered eutrophic and prefers higher concentrations of 10-50 mM ammonium (Prosser et al., 2014).

Previous studies on the model organism $N$. europaea, a eutrophic strain, showed that both hydroxylamine $\left(\mathrm{NH}_{2} \mathrm{OH}\right)$ oxidation and $\mathrm{NO}_{2}^{-}$reduction can lead to significant emission of $\mathrm{N}_{2} \mathrm{O}$ (Cantera and Stein, 2007; Kozlowski et al., 2014). Previous work also revealed that NorB, but not NirK, is required for production of $\mathrm{N}_{2} \mathrm{O}$ by $N$. europaea (Kozlowski et al., 2014). This observation, in addition to the lack of annotated NIR or NOR genes in some closed AOB genomes, has brought into question whether all AOB can even perform nitrifier denitrification and emit $\mathrm{N}_{2} \mathrm{O}$ under similar conditions as $N$. europaea. There is also a question of whether uncharacterized NIR and/or NOR enzymes are expressed in $\mathrm{AOB}$ that can contribute to the process. The production and metabolism of $\mathrm{NO}$ and its role in $\mathrm{N}_{2} \mathrm{O}$ emission is another understudied aspect of nitrogen oxide metabolism in AOB; N. multiformis ATCC 25196 was recently found to emit large quantities of $\mathrm{NO}$ during active $\mathrm{NH}_{3}$-oxidation (Kozlowski et al., 2016c).

Due to the lack of comparative information on nitrogen oxide metabolism in $\mathrm{AOB}$, five strains representing different phylogenies and trophic states and with closed genomes were selected for this study. Our main objectives were to: (i) compare $\mathrm{NO}$ and $\mathrm{N}_{2} \mathrm{O}$ production profiles of the five strains during $\mathrm{NH}_{3}$ and $\mathrm{NH}_{2} \mathrm{OH}$ oxidation and over a period of anoxia when nitrifier denitrification is most active in N. europaea, and (ii) determine whether gene content, trophic state, and/or phylogeny of these diverse $\mathrm{AOB}$ were predictive of their capacity to metabolize and/or emit $\mathrm{NO}$ or $\mathrm{N}_{2} \mathrm{O}$.

\section{MATERIALS AND METHODS}

\section{Strains and Cultivation}

AOB strains included N. europaea ATCC $19718^{\mathrm{T}}$, N. communis strain $\mathrm{Nm}^{\mathrm{T}}$, Nitrosomonas sp. Is79A3, N. ureae $\mathrm{Nm}_{10}{ }^{\mathrm{T}}$, and N. multiformis ATCC 25196 ${ }^{\mathrm{T}}$. All strains have closed genomes and grow under similar cultivation conditions to allow for proper comparisons across phylotypes and trophic status. Furthermore, an AOB strain was selected from each cluster in the Betaproteobacteria with a cultured representative, 3, 6, 7, and 8 (based on 16S rRNA phylogeny; Norton, 2011), with the exception of the newly cultured cluster $0 \mathrm{~N}$. lacus sp. nov. as its genome is not yet closed (Garcia et al., 2013; Urakawa et al., 2014). AOB cultures were grown and maintained in Wheaton bottles $(250 \mathrm{~mL})$ sealed with caps inlayed with butyl rubber stoppers at $28^{\circ} \mathrm{C}$ in $100 \mathrm{~mL}$ HEPES-buffered HK medium (Krümmel and Harms, 1982) and phenol red as $\mathrm{pH}$ indicator ( $\mathrm{pH}$ of 7.5-8) with either $5 \mathrm{mM}\left(\mathrm{NH}_{4}\right)_{2} \mathrm{SO}_{4}$ for the meso- and eutrophic strains (N. europaea, N. communis, and N. multiformis), or $2.5 \mathrm{mM}$ $\left(\mathrm{NH}_{4}\right)_{2} \mathrm{SO}_{4}$ for the oligotrophic strains (Nitrosomonas sp. Is79A3 and N. ureae; Prosser et al., 2014). All cultures were transferred (5\% v/v inoculum) when ca. $80 \%$ of the $\mathrm{NH}_{3}$ substrate was consumed as determined by $\mathrm{NO}_{2}^{-}$concentration (Bollmann et al., 2011). The $\mathrm{pH}$ of all cultures was adjusted as needed with $10 \%$ $\mathrm{NaHCO}_{3}$.

\section{Phylogenetic and Genome Analysis of AOB}

PhyloPhlAn (Segata et al., 2013) was used to generate and analyze the genome-wide phylogeny of AOB. Genomes of 14 AOB were obtained from the National Center for Biotechnology Information ${ }^{1}$. All of the predicted protein-coding sequences for each genome were exported into PhyloPhlAn to identify and align 400 broadly conserved protein sequences between all of the input genomes. PhyML 3.0 (Guindon et al., 2010) was used to construct a maximum likelihood phylogeny using the Gammaproteobacteria as the root and node support was calculated using 500 bootstrap replicates.

\section{Microrespirometry Experiments}

Instantaneous microrespirometry (MR) experiments of $\mathrm{AOB}$ are described in detail elsewhere (Kozlowski et al., 2016c). Briefly, $\mathrm{MR}$ experiments were performed at $28^{\circ} \mathrm{C}$ in a $10 \mathrm{~mL} \mathrm{2-port}$ injection lid glass chamber (Unisense, Aarhus, Denmark). For instantaneous experiments all strains were grown to late-log phase (7-8 $\mathrm{mM} \mathrm{NO}_{2}^{-}$), filtered on Supor ${ }^{\circledR} 2000.2 \mu \mathrm{m}$ filters (Pall, Ann Arbor WI), and rinsed three times with $\mathrm{NH}_{3}$-free HK media (Krümmel and Harms, 1982). Ca. $1 \times 10^{10}$ total cells were used per experiment for all strains as determined by direct cell count by phase-contrast light microscopy. All cells for instantaneous MR measurements were in a planktonic state, resuspended in $\mathrm{NH}_{3}$-free $\mathrm{HK}$ medium and provided either $2 \mathrm{mM}$ $\mathrm{NH}_{4} \mathrm{Cl}$ as substrate or pulses of $250 \mu \mathrm{M}$ or $100 \mu \mathrm{M} \mathrm{NH}{ }_{2} \mathrm{OH}-\mathrm{HCl}$ (final chamber concentration; $99.999 \%$ purity, Sigma-Aldrich, St

\footnotetext{
${ }^{1}$ http://www.ncbi.nlm.nih.gov/genome/
} 
Louis, MO, USA). Previous testing revealed that all strains could tolerate up to $250 \mu \mathrm{M} \mathrm{NH} \mathrm{N}_{2} \mathrm{OH}$ (final chamber concentration) with the exception of $N$. communis which was unable to tolerate more than $100 \mu \mathrm{M} \mathrm{NH} \mathrm{NH}_{2} \mathrm{OH}$ (final chamber concentration) per injection (data not shown). Chamber $\mathrm{O}_{2}$ was determined by an $\mathrm{O}_{2}$ electrode (OX-MR $500 \mu \mathrm{m}$ tip diameter $\mathrm{MR}$ oxygen electrode; Unisense, Aarhus, DenmarK), $\mathrm{N}_{2} \mathrm{O}$ concentration was measured using an $\mathrm{N}_{2} \mathrm{O}-500 \mathrm{~N}_{2} \mathrm{O}$ minisensor electrode with $500 \mu \mathrm{m}$ tip diameter (Unisense, Aarhus, DenmarK), and NO was measured using an ami-600 NO sensor with $600 \mu \mathrm{m}$ tip diameter (Innovative Instruments Inc., Tampa, FL, USA). The availability of $\mathrm{O}_{2}$ in the MR chamber, a closed system, was ca. $243 \mu \mathrm{M} \mathrm{O}_{2}$ based on equilibrium $\mathrm{O}_{2}$ concentration at operating temperatures and medium salinities for experiments performed without $\mathrm{N}_{2}$-sparged medium.

\section{Chemical Controls}

Chemical controls were performed to determine the production of $\mathrm{N}_{2} \mathrm{O}$ from reactivity of $\mathrm{NH}_{2} \mathrm{OH}$ with media $+\mathrm{NO}_{2}^{-}$, or from killed-cells $\left(1 \times 10^{10}\right.$ total cells) with media $+\mathrm{NH}_{2} \mathrm{OH}$. Chemical controls used $\mathrm{N}_{2}$-sparged medium (to achieve $0-3 \% \mathrm{O}_{2}$ saturation in liquid phase) containing $250 \mu \mathrm{M} \mathrm{NaNO}_{2}$ and then adding $250 \mu \mathrm{M} \mathrm{NH}_{2} \mathrm{OH}$ (final chamber concentration) to reflect conditions in the chamber when testing for $\mathrm{NO}_{2}^{-}$consumption by $\mathrm{AOB}$ as an alternate terminal electron acceptor with $\mathrm{NH}_{2} \mathrm{OH}$ as the electron donor. Cells for control experiments were heatkilled by boiling for $30 \mathrm{~min}$. The heat-killed cell controls involved addition of $250 \mu \mathrm{M} \mathrm{NH} \mathrm{H}_{2} \mathrm{OH}$ to the MR-chamber containing $\mathrm{N}_{2}$ sparged media with $1 \times 10^{10}$ total heat-killed cells of each AOB strain. $\mathrm{N}_{2} \mathrm{O}$ was measured as described above.

\section{RESULTS AND DISCUSSION}

\section{Phylogeny and Comparative Gene Inventory of AOB}

A whole-genome analysis utilizing PhyloPhlAn showed that each of the 5 Betaproteobacteria AOB chosen for physiological analysis in the present study separated into individual clades (Figure 1). The separation of each $\mathrm{AOB}$ into a unique branch, using 400 core protein markers from available complete genome sequences to form a high-resolution tree, shows a clearer and greater separation than currently available $16 \mathrm{~S}$ rRNA or amoA single gene sequence phylogenies (Norton, 2011). The results of this multiple-marker, genome-wide, comparison highlight a need to reevaluate and perhaps reclassify some members of Nitrosomonas into different genera.

Comparison of inventory involved in central ammoniaoxidizing metabolism and NOx production revealed differences across the 5 strains (Table 1). In agreement with previous analyses of AMO gene clusters in betaproteobacterial AOB (Klotz and Stein, 2011) all AOB of the current study contain 1-2 copies of the amoCABED cluster encoding ammoniamonooxygenase (Table 1). All strains encoded at least one monocistronic copy of the amoC gene with the exception of $N$. communis (Table 1), a feature shared in common with the gammaproteobacerial AOB (Klotz et al., 2006; Arp et al., 2007;
Campbell et al., 2011). The singleton AmoC is proposed to participate in cellular recovery from stressors such as elevated temperatures and starvation by stabilizing the AMO complex in the membrane of $N$. europaea (Berube and Stahl, 2012). Also, every strain encoded at least one copy of the amoD gene in tandem with $a m o E$, a common feature of betaproteobacterial AOB still needing biochemical characterization (Klotz and Stein, 2011). It is also common for betaproteobacterial AOB to encode 2-3 complete or incomplete (lacking $c y c B$ ) copies of the hao $A B$ $c y c A B$ cluster (Arp et al., 2007). However, N. ureae represents the first sequenced $\mathrm{AOB}$ to harbor 4 complete copies of the Hydroxylamine dehydrogenase (HAO) gene cluster (Table 1). Knockouts of one or two haoA gene copies from $N$. europaea did not result in a significant phenotype (Hommes et al., 2002), suggesting that the multiple copies are isofunctional. However, knockouts of individual $a m o A$ or $a m o B$ gene copies in $N$. europaea did result in different phenotypes, suggesting that operons encoding AMO are differentially regulated (Stein et al., 2000). For N. ureae and perhaps Nitrosomonas sp. AL212 (Suwa et al., 2011), additional gene clusters encoding AMO and HAO could be a strategy to thrive in oligotrophic environments to gain maximum reductant from available substrate; however, further studies are required to validate whether all of the gene copies are expressed, isofunctional, and/or differentially regulated. As with $N$. europaea and N. eutropha, one copy of the HAO gene cluster in $N$. communis lacks $c y c B$ (Table 1), encoding cytochrome $\mathrm{C}_{\mathrm{m}} 552$ (Arp et al., 2007). All strains, with the exception of Nitrosomonas sp. Is79A3 (Bollmann et al., 2013), encode the AOB-specific red copper protein nitrosocyanin (Table 1) proposed to be involved in the $\mathrm{NH}_{3}$-oxidation pathway as a redox sensitive electron carrier (Arciero et al., 2002; Sayavedra-Soto and Arp, 2011).

Analysis of NIR and NOR genes revealed that N. communis is the only sequenced and closed AOB genome without a coppercontaining nitrite reductase (nirK; Kozlowski et al., 2016b) (Table 1). This is interesting as nirK is present in all published genomes of ammonia-oxidizing Thaumarchaeota (AOA; Bartossek et al., 2010), is highly expressed in metatranscriptomes (Hollibaugh et al., 2011; Radax et al., 2012), and is important for efficient substrate oxidation in $N$. europaea (Cantera and Stein, 2007; Kozlowski et al., 2014). Of the 5 strains, only $N$. europaea contains the operonic nirK and NO-responsive $n s r R$ transcriptional regulator (Chain et al., 2003; Table 1), features shared by the closely related $N$. eutropha C-91 strain (Stein et al., 2007) (Figure 1). All the Nitrosomonas strains, but not N. multiformis, encode the NO-responsive NnrS transcriptional regulator. Two strains, Nitrosomonas sp. Is79A3 and $N$. ureae, both within the Cluster $6 \mathrm{AOB}$, lack annotated operons for cytochrome $c$ nitric oxide reductases (Bollmann et al., 2013; Kozlowski et al., 2016a) (Table 1). The genome of the closely related Nitrosomonas sp. AL212 (Figure 1) does encode nor $C B Q D$ but lacks genes for the other NOR frequently found in AOB genomes, norSY-senC-orf1 (Suwa et al., 2011). We hypothesize that environments with low substrate availability do not experience oversaturation of $\mathrm{NH}_{3}$ and thus preclude accumulation of $\mathrm{N}$-oxides such as $\mathrm{NH}_{2} \mathrm{OH}$ and $\mathrm{NO}$ (Hooper and Terry, 1979). Thus, NORs may not be not required by some oligotrophic AOB as nitrosative stress should be minimal. 


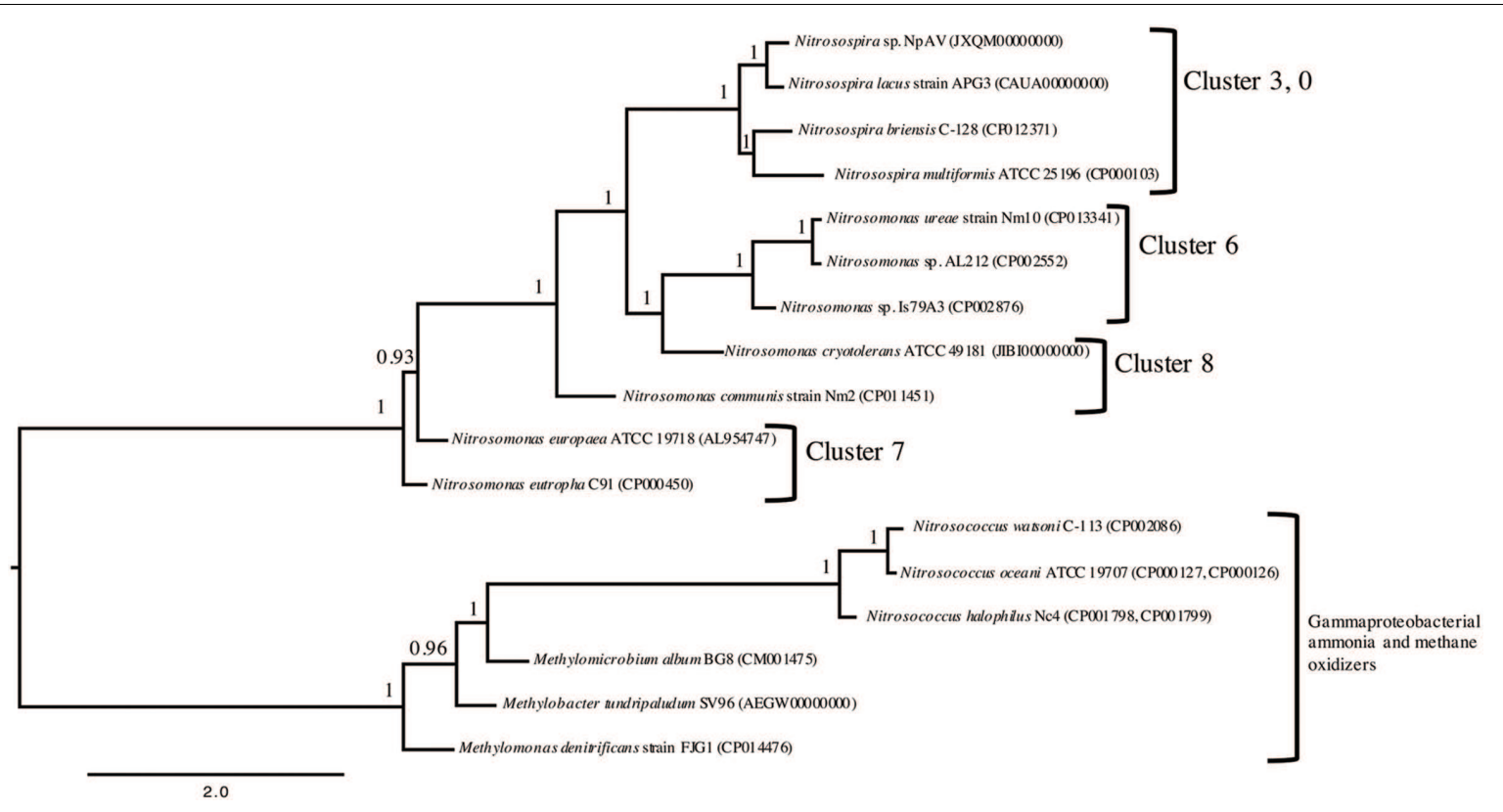

FIGURE 1 | Rooted maximum likelihood phylogeny of 14 publically available genomes of ammonia oxidizing bacteria based on 400 broadly conserved amino-acid sequences. PhyloPhIAn (Segata et al., 2013) was used to identify and align the amino-acid sequences in all input genomes. The tree was constructed using PhyML 3.0 (Guindon et al., 2010) with the Gammaproteobacteria as the root. Bootstrap values (as a proportion of 500 replicates) are denoted above the branches and branch lengths correspond to sequence differences as indicated by the scale bar at the bottom.

However, testing of strains such as Nitrosomonas AL212, an oligotrophic, NOR-encoding strain, must be accomplished to determine whether trophic state or gene content is more predictive of nitrifier denitrification activity. N. multiformis does not have an annotated cytochrome P460 (cytL) whereas $N$. communis has two copies (Table 1), a feature shared with Nitrosomonas sp. AL212 (Suwa et al., 2011). Cytochrome P460 has a proposed role in detoxification of $\mathrm{NOx}$ through the simultaneous oxidation $\mathrm{NH}_{2} \mathrm{OH}$ and $\mathrm{NO}$ to $\mathrm{NO}_{2}^{-}$(Elmore et al., 2007; Stein, 2011) and may be important for alleviating nitrosative stress in AOB lacking NORs. All 5 genomes also contain sequences for cytochrome $c$ ' beta, potentially having NOR activity (Elmore et al., 2007; Stein, 2011). Future work with focus on the transcription and activities of cytochromes P460 and c' beta under conditions of nitrosative stress would better clarify the role of both enzymes as substitutes for lack of annotated NORs.

\section{Comparison of Instantaneous NOx Production from AOB during Oxidation of $\mathrm{NH}_{3}$ or $\mathrm{NH}_{2} \mathrm{OH}$}

Measurement of $\mathrm{NO}$ or $\mathrm{N}_{2} \mathrm{O}$ production during oxidation of $\mathrm{NH}_{3}$ or $\mathrm{NH}_{2} \mathrm{OH}$ were compared among the 5 strains and revealed that all $\mathrm{AOB}$ produce measureable quantities of $\mathrm{NO}$ during active oxidation of $\mathrm{NH}_{3}$ (Figures 2A,C,E,G,I). Although each $\mathrm{AOB}$ had a unique and dynamic NO production profile, making comparative rate calculations impractical, all strains produced $>50 \mathrm{nM}$ NO (per $1 \times 10^{10}$ total cells) prior to anoxia in the MR chamber. $N$. europaea produced the least amount of NO compared to the other strains during active oxidation and prior to anoxia (Figure 2A; Supplementary Table S1). As reported previously (Kozlowski et al., 2016c) N. multiformis began re-consuming $\mathrm{NO}$ once ca. $50 \% \mathrm{O}_{2}$ was left in the MRchamber (Figure 2I) and both $N$. europaea and $N$. communis re-consumed a small amount of NO following anoxia in the MRchamber (Figures 2A,C). Interestingly, either immediately upon $\mathrm{O}_{2}$ depletion in the case of Nitrosomonas sp. Is79A3 (Figure 2E) or ca. 5 min. post-anoxia for N. ureae, these two strains released massive quantities of $\mathrm{NO}$ outside the limit for measurement by the ami-600 NO microsensor (Figures 2E,G). Unlike the other AOB strains, neither Nitrosomonas sp. Is79A3 nor N. ureae reconsumed $\mathrm{NO}$ during active $\mathrm{NH}_{3}$-oxidation or following anoxia in the MR-chamber.

Measurement of NO during active substrate oxidation has so far only been studied in pure cultures of N. europaea (Kester et al., 1997; Yu and Chandran, 2010; Yu et al., 2010) and N. multiformis (Kozlowski et al., 2016c), both of which have annotated nirK, norB, and nor $Y$ genes (Table 1). It is known, however, that the thaumarchaeotal ammonia-oxidizers (AOA) also produce NO during $\mathrm{NH}_{3}$-oxidation (Martens-Habbena et al., 2015; Kozlowski et al., 2016c); however, they retain very tight control over its production and consumption (Kozlowski et al., 2016c). There are significant similarities in NO profiles of the AOA Nitrososphaera viennensis and the oligotrophic $\mathrm{AOB}$ of the present study in that once $\mathrm{O}_{2}$ was depleted in the MR chamber substantial quantities of NO were released (Figures 2E,G; Kozlowski et al., 2016c). This similarity between the AOA and the oligotrophic AOB, both lineages with a low $K_{\mathrm{m}}$ and high affinity for ammonium (Martens-Habbena et al., 2009; Stahl and de la Torre, 2012; 


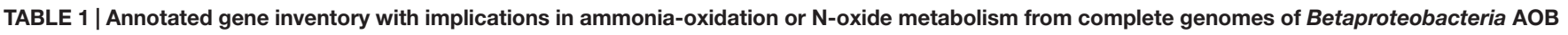
utilized in the present study.

\begin{tabular}{|c|c|c|c|c|c|}
\hline Strain & $\begin{array}{l}\text { Nitrosomonas } \\
\text { europaea } \\
\text { ATCC } 19718\end{array}$ & $\begin{array}{l}\text { Nitrosomonas } \\
\text { communis Nm2 }\end{array}$ & $\begin{array}{l}\text { Nitrosomonas sp. } \\
\text { Is79A3 }\end{array}$ & $\begin{array}{l}\text { Nitrosomonas } \\
\text { ureae Nm10 }\end{array}$ & $\begin{array}{l}\text { Nitrosospira } \\
\text { multiformis } \\
\text { ATCC25196 }\end{array}$ \\
\hline $\begin{array}{l}\text { Ammonia } \\
\text { monooxygenase } \\
(A M O)\end{array}$ & $\begin{array}{l}\text { amoCABED } \\
\text { NE2064-59 } \\
\text { NE0945-40 } \\
\text { amoC } \\
\text { NE1411 }\end{array}$ & $\begin{array}{l}\text { amoCABED } \\
\text { AWW31_01090-70 } \\
\text { AWW31_05385-65 }\end{array}$ & $\begin{array}{l}\text { amoCABED } \\
\text { Nit79A3_0471-75 } \\
\text { Nit79A3_2886-82 } \\
\text { amoCAB } \\
\text { Nit79A3_1079-81 } \\
\text { amoC } \\
\text { Nit79A3_1233 } \\
\text { Nit79A3_1595 }\end{array}$ & $\begin{array}{l}\text { amoCABED } \\
\text { ATY38_01315-295 } \\
\text { ATY38_07250-70 } \\
\text { amoCAB } \\
\text { ATY38_13760-50 } \\
\text { amoCE } \\
\text { ATY38_06315-10 } \\
\text { amoC } \\
\text { ATY38_09265 }\end{array}$ & $\begin{array}{l}\text { amoCABED } \\
\text { Nmul_A2326-22 } \\
\text { amoCAB } \\
\text { Nmul_A0798-800 } \\
\text { amoC } \\
\text { Nmul_A0177 } \\
\text { Nmul_A2467 }\end{array}$ \\
\hline $\begin{array}{l}\text { Hydroxylamine } \\
\text { dehydrogenase }(H A O)\end{array}$ & $\begin{array}{l}\text { haoAB-cycAB } \\
\text { NE0962-59 } \\
\text { NE2339-36 } \\
\text { haoAB-cycA } \\
\text { NE2044-42 }\end{array}$ & $\begin{array}{l}\text { haoAB-cycAB } \\
\text { AAW31_01285-70 } \\
\text { AAW31_16290-75 } \\
\text { haoAB-cycA } \\
\text { AAW31_18275-65 }\end{array}$ & $\begin{array}{l}\text { haoAB-cycAB } \\
\text { Nit79A3_0807-10 } \\
\text { Nit79A3_0822-25 } \\
\text { Nit79A3_2942-39 }\end{array}$ & $\begin{array}{l}\text { haoAB-cycAB } \\
\text { ATY38_00070-55 } \\
\text { ATY38_06640-55 } \\
\text { ATY38_10080-95 } \\
\text { ATY38_15220-05 }\end{array}$ & $\begin{array}{l}\text { haoAB-cycAB } \\
\text { Nmul_A0805-02 } \\
\text { Nmul_A1082-85 } \\
\text { Nmul_A2662-59 }\end{array}$ \\
\hline Nitrosocyanin & NE0143 & AAW31_00185 & Not Present & ATY38_00645 & Nmul_A1601 \\
\hline $\begin{array}{l}\text { Nitrite reductase } \\
\text { (NirK) }\end{array}$ & $\begin{array}{l}\text { ncgABC-nirK } \\
\text { NE0924 }\end{array}$ & Not Present & $\begin{array}{l}\text { nirk } \\
\text { Nit79A3_2335 }\end{array}$ & $\begin{array}{l}\text { nirK } \\
\text { ATY38_00595 }\end{array}$ & $\begin{array}{l}\text { nirk } \\
\text { Nmul_A1998 }\end{array}$ \\
\hline $\begin{array}{l}\text { Cytochrome c nitric } \\
\text { oxide reductases }\end{array}$ & $\begin{array}{l}\text { norCBQD } \\
\text { NE2003-06 } \\
\text { norSY-senC-orf1 } \\
\text { NE0683-86 }\end{array}$ & $\begin{array}{l}\text { norCBQD } \\
\text { AAW31_10555-70 } \\
\text { norSY-senC-orf1 } \\
\text { AAW31_05895-910 }\end{array}$ & Not Present & Not Present & $\begin{array}{l}\text { norCBQD } \\
\text { Nmul_A1256-43 } \\
\text { norSY-senC-orf1 } \\
\text { Nmul_A2667-64 }\end{array}$ \\
\hline $\begin{array}{l}\text { Cytochrome c' beta } \\
\text { (cytS) }\end{array}$ & NE0824 & AAW31_17525 & Nit79A3_0363 & ATY38_05410 & Nmul_A2484 \\
\hline $\begin{array}{l}\text { Cytochrome P460 } \\
\text { (cytL) }\end{array}$ & NE0011 & $\begin{array}{l}\text { AAW31_02040 } \\
\text { AAW31_00880 }\end{array}$ & Nit79A3_1628 & ATY38_00655 & Not Present \\
\hline $\begin{array}{l}\text { NO-responsive } \\
\text { transcriptional } \\
\text { regulator (NsrR) }\end{array}$ & NE0926 & Not Present & Not Present & Not Present & Not Present \\
\hline $\begin{array}{l}\text { NO-responsive } \\
\text { transcriptional } \\
\text { regulator (NnrS) }\end{array}$ & NE1722 & $\begin{array}{l}\text { AAW31_04320 } \\
\text { AAW31_06015 }\end{array}$ & Nit79A3_3412 & ATY38_04220 & Not Present \\
\hline
\end{tabular}

Locus tags from the sequenced and publicly accessible genomes are presented for each annotated gene and gene cluster.

Prosser et al., 2014), could be explained by a lack of NOR genes to combat high intracellular NO experienced during anoxia either due to release of $\mathrm{NO}$ directly from the $\mathrm{NH}_{3}$-oxidation pathway, in the case of AOA (Kozlowski et al., 2016c), or perhaps from $\mathrm{NO}_{2}^{-}$reduction in the case of the AOB (Stein, 2011). Importantly, the $\mathrm{N}_{2} \mathrm{O}$ measured from $N$. viennensis following $\mathrm{NH}_{3}$-oxidation and over an extended period of anoxia was a result of $\mathrm{NO}$ release and abiotic media-dependent conversion to $\mathrm{N}_{2} \mathrm{O}$ (Kozlowski et al., 2016c). Also, in the nitrifier-denitrification pathway of $N$. europaea, it should be noted that NorB is required for $\mathrm{NO}_{2}^{-}$reduction to $\mathrm{N}_{2} \mathrm{O}$ (Kozlowski et al., 2014). This suggests that the lack of annotated NOR precludes a complete nitrifierdenitrification pathway in ammonia-oxidizers.

Following $\mathrm{O}_{2}$ depletion and in the presence of $\mathrm{NO}_{2}^{-}$some AOB can perform nitrifier denitrification (Stein, 2011; Kozlowski et al., 2014). This was tested in the present study by measurement of $\mathrm{N}_{2} \mathrm{O}$ during active $\mathrm{NH}_{3}$ - or $\mathrm{NH}_{2} \mathrm{OH}$-oxidation and through a period of anoxia (Figures 2 and 3 ). It should be noted that the $K_{\mathrm{m}}$ for the copper-containing nitrite reductase, NirK, has not been tested for $\mathrm{AOB}$ and therefore it is not known whether ca. 162 or $243 \mu \mathrm{M} \mathrm{NO}_{2}^{-}$following $\mathrm{NH}_{3}$ or $\mathrm{NH}_{2} \mathrm{OH}$ oxidation, respectively, in the chamber is at saturation for NirK.

Following $\mathrm{NH}_{3}$-oxidation, $\mathrm{N}_{2} \mathrm{O}$ was produced by all strains in the MR-chamber (Figures 2B,D,F,H,J). A greater delay of ca. 3 min in measureable $\mathrm{N}_{2} \mathrm{O}$ was seen from traces with both $N$. communis (Figure 2D) and $N$. ureae (Figure $2 \mathbf{H}$ ). The lowest concentrations and slowest rates of $\mathrm{N}_{2} \mathrm{O}$ came from N. communis and N. multiformis (Figures 2D,J; Supplementary Table S1). N. europaea $\mathrm{N}_{2} \mathrm{O}$ production in the MR-chamber began immediately following $\mathrm{O}_{2}$-depletion and was produced at a rate of $0.47 \mu \mathrm{M} \mathrm{N} \mathrm{N}_{2} \mathrm{O}$ per $10^{10}$ cells $^{1}$ per minute (Figure 2B; Supplementary Table S1). As with NO production, 


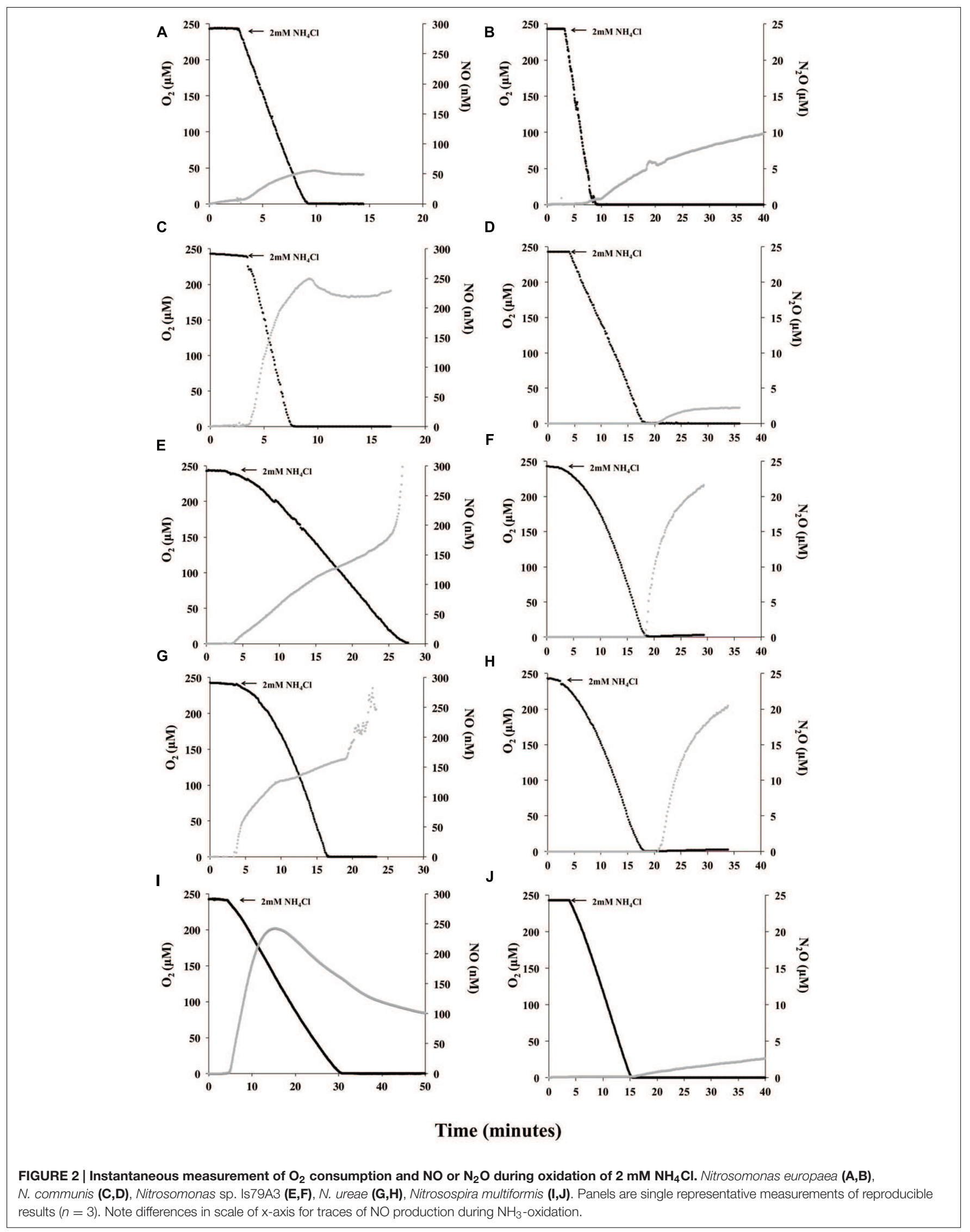


A

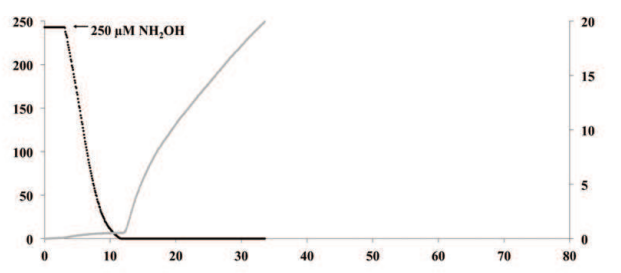

B

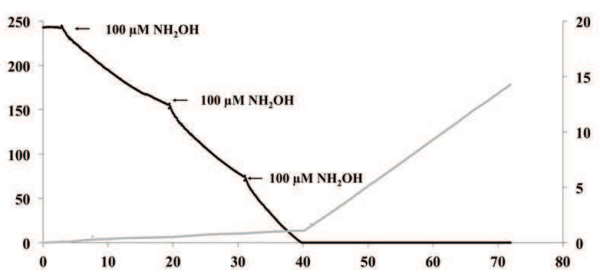

C

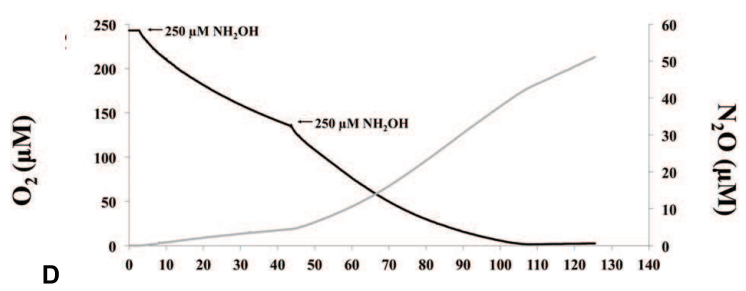

D

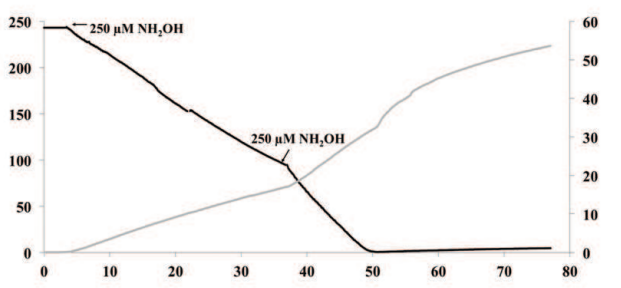

E

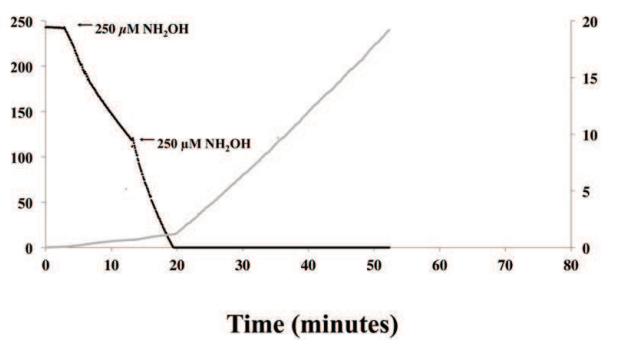

FIGURE 3 | Instantaneous measurement of $\mathrm{O}_{2}$ consumption and $\mathrm{N}_{2} \mathrm{O}$ production during oxidation of $\mathrm{NH}_{2} \mathrm{OH}$. N. europaea (A), N. communis (B), Nitrosomonas sp. Is79A3 (C), N. ureae (D), or N. multiformis (E). Note the $\mathrm{x}$-axis for Nitrosomonas $\mathrm{sp}$. Is79A3 differs from the other traces. Nitrosomonas sp. Is79A3 and $N$. ureae have different $y$-axes for $\mathrm{N}_{2} \mathrm{O}$ production.

both Nitrosomonas sp. Is79A3 and N. ureae had similar $\mathrm{N}_{2} \mathrm{O}$ traces with similarly fast rates for $\mathrm{N}_{2} \mathrm{O}$ production following anoxia (Figures 2F,H; Supplementary Table S1).

With $\mathrm{NH}_{2} \mathrm{OH}$ as substrate, the majority of $\mathrm{N}_{2} \mathrm{O}$ in the MR-chamber from $N$. europaea (Figure 3A), N. communis (Figure 3B), and N. multiformis (Figure 3E) was produced in a linear fashion directly following anoxia suggesting enzymatic reduction of available $\mathrm{NO}_{2}^{-}$to $\mathrm{N}_{2} \mathrm{O}$ and thus nitrifier denitrification. However, in the case of both Nitrosomonas sp. Is79A3 (Figure 3C) and $N$. ureae (Figure 3D) the majority of $\mathrm{N}_{2} \mathrm{O}$ was measured during active $\mathrm{NH}_{2} \mathrm{OH}$-oxidation with production in both traces slowing upon complete $\mathrm{O}_{2}$-depletion. Furthermore, the quantity of $\mathrm{N}_{2} \mathrm{O}$ measured from both Nitrosomonas sp. Is79A3 and $N$. ureae during active $\mathrm{NH}_{2} \mathrm{OH}$ oxidation was much greater overall than that produced from any other $\mathrm{AOB}$, suggesting a greater overall release of $\mathrm{NO}$, or other reactive intermediates, during this process (Law et al., 2012) (Figure 3).

It is interesting that $\mathrm{N}$. communis, the only AOB lacking NirK, had very weak non-linear $\mathrm{N}_{2} \mathrm{O}$ production from $\mathrm{NH}_{3}$, yet strong linear production when $\mathrm{NH}_{2} \mathrm{OH}$ was provided (Figures 2D and 3B). The linearity of $\mathrm{N}_{2} \mathrm{O}$ formation with $\mathrm{NH}_{2} \mathrm{OH}$ as substrate suggests that there is an enzymatic pathway for $\mathrm{N}_{2} \mathrm{O}$ formation under anoxic conditions, but this pathway is not active when $\mathrm{NH}_{3}$ is provided as substrate. This observation provides insight into the function of unidentified enzymology that links direct $\mathrm{NH}_{2} \mathrm{OH}$ oxidation to $\mathrm{N}_{2} \mathrm{O}$ production in N. communis that requires further investigation. Similarly, an N. europaea NirK deficient mutant was also able to reduce $\mathrm{NO}_{2}^{-}$to $\mathrm{N}_{2} \mathrm{O}$ (Cantera and Stein, 2007; Kozlowski et al., 2014), further supporting the presence of alternate, as yet unidentified, NIRs in AOB.

\section{Contribution of AOB to Abiotic $\mathrm{N}_{\mathbf{2}} \mathrm{O}$}

The $\mathrm{N}_{2} \mathrm{O}$ profiles of both Nitrosomonas sp. Is79A3 and N. ureae post-anoxia (Figures $2 \mathbf{F}, \mathbf{H}$ ) are congruent with a rapid and abundant release of $\mathrm{NO}$ (Figures $2 \mathrm{E}, \mathbf{G}$ ) being abiotically reduced to $\mathrm{N}_{2} \mathrm{O}$, a characteristic trait observed in the AOA N. viennensis (Kozlowski et al., 2016c). Also in support of an abiotic origin of $\mathrm{N}_{2} \mathrm{O}$ for both Nitrosomonas sp. Is79 and N. ureae in comparison to the other AOB strains (Figure 3) is the observation that the majority of $\mathrm{N}_{2} \mathrm{O}$ was measured during active oxidation of $\mathrm{NH}_{2} \mathrm{OH}$. Accumulation of $\mathrm{NH}_{2} \mathrm{OH}$ can lead to $\mathrm{NO}$ and $\mathrm{N}_{2} \mathrm{O}$ production at the active site of the HAO (Hooper and Terry, 1979; Stein, 2011). A high enough concentration of NO will react with components of the $\mathrm{HK}$ medium to form $\mathrm{N}_{2} \mathrm{O}$ as well (Kozlowski et al., 2016c). Interestingly, the lack of NirK did not cause significant production of $\mathrm{N}_{2} \mathrm{O}$ during active $\mathrm{NH}_{2} \mathrm{OH}$-oxidation by $\mathrm{N}$. communis, as shown previously for NirK-deficient $N$. europaea (Cantera and Stein, 2007), suggesting a different configuration of the ammonia-oxidation pathway among AOB that lack NirK.

In previous control experiments the intermediate $\mathrm{NH}_{2} \mathrm{OH}$ reacted with heat-killed cell moieties of the AOA, N. viennensis EN76, to produce abiological $\mathrm{N}_{2} \mathrm{O}$ (Kozlowski et al., 2016c). In the present study, abiotic and heat-killed cell controls were performed to demonstrate if $\mathrm{NH}_{2} \mathrm{OH}$ could react with either media components or heat-killed cells to produce $\mathrm{N}_{2} \mathrm{O}$ in the absence of active cellular functioning (Supplementary Figure S1). $\mathrm{NH}_{4}^{+}$-free $\mathrm{HK}$ medium $+\mathrm{NaNO}_{2}$ or with heatkilled $\mathrm{AOB}$ and addition of $250 \mu \mathrm{M} \mathrm{NH} \mathrm{NH}_{2} \mathrm{OH}$ showed that medium $+\mathrm{NaNO}_{2}$ or medium with heat-killed $\mathrm{N}$. europaea, N. communis, and N. multiformis $+\mathrm{NH}_{2} \mathrm{OH}$ did not facilitate significant measureable $\mathrm{N}_{2} \mathrm{O}$ (Supplementary Figure S1). However, heat-killed cells of both Nitrosomonas sp. Is79A3 and $N$. ureae both produced measureable $\mathrm{N}_{2} \mathrm{O}$ following addition of $250 \mu \mathrm{M} \mathrm{NH} \mathrm{H}_{2} \mathrm{OH}$. The reactivity of cellular moieties with $\mathrm{NH}_{2} \mathrm{OH}$ is further evidence of similarities among these oligotrophic $\mathrm{AOB}$ and the $\mathrm{AOA}$ as heat-killed controls of 
$N$. viennensis cells showed similar reactivity with $\mathrm{NH}_{2} \mathrm{OH}$ in growth medium (Kozlowski et al., 2016c). Taken altogether, the data support that $\mathrm{N}_{2} \mathrm{O}$ is produced abiotically from Nitrosomonas sp. Is79 and $N$. ureae similarly to that of the AOA, N. viennensis, likely due to their massive release of $\mathrm{NO}$ at anoxia and also the reactivity of their cellular moieties with $\mathrm{NH}_{2} \mathrm{OH}$ and other medium constituents.

\section{CONCLUSION}

The present study highlights many new findings in the comparative phylogeny and nitrogen oxide metabolism of betaproteobaterial AOB. First, the data support the previous study of $N$. europaea that a cytochrome $c$-dependent NOR is required for nitrifier denitrification activity (Kozlowski et al., 2014). Second, the release of NO by the two oligotrophic strains in Cluster 6 of the AOB likely contributes to abiotic $\mathrm{N}_{2} \mathrm{O}$ production (chemo-denitrification), especially under environmental conditions that facilitate $\mathrm{NO}$ or $\mathrm{NH}_{2} \mathrm{OH}$ release (Jones et al., 2015; Zhu-Barker et al., 2015). This observation is congruent with the physiology of the oligotrophic AOA that lack NOR (Kozlowski et al., 2016c). Third, this study showcases the utility of comparative physiological studies on pure cultures of ammonia-oxidizers to characterize the diversity of mechanisms for $\mathrm{NOx}$ production and ultimately for $\mathrm{N}_{2} \mathrm{O}$ release to the environment.

\section{REFERENCES}

Arciero, D. M., Pierce, B. S., Hendrich, M. P., and Hooper, A. B. (2002). Nitrosocyanin, a red cupredoxin-like protein from Nitrosomonas europaea. Biochemistry 41, 1703-1709. doi: 10.1021/bi015908w

Arp, D. J., Chain, P. S. G., and Klotz, M. G. (2007). The impact of genome analyses on our understanding of ammonia-oxidizing bacteria. Annu. Rev. Microbiol. 61, 503-528. doi: 10.1146/annurev.micro.61.080706.093449

Bartossek, R., Nicol, G. W., Lanzen, A., Klenk, H.-P., and Schleper, C. (2010). Homologues of nitrite reductases in ammonia-oxidizing archaea: diversity and genomic context. Environ. Microbiol. 12, 1075-1088. doi: 10.1111/j.14622920.2010.02153.x

Beaumont, H. J. E., Hommes, N. G., Sayavedra-Soto, L. A., Arp, D. J., Arciero, D. M., Hooper, A. B., et al. (2002). Nitrite reductase of Nitrosomonas europaea is not essential for production of gaseous nitrogen oxides and confers tolerance to nitrite. J. Bacteriol. 184, 2557-2560. doi: 10.1128/JB.184.9.2557-2560.2002

Beaumont, H. J. E., van Schooten, B., Lens, S. I., Westerhoff, H. V., and van Spanning, R. J. M. (2004). Nitrosomonas europaea expresses a nitric oxide reductase during nitrification. J. Bacteriol. 186, 4417-4421. doi: 10.1128/JB.186.13.4417-4421.2004

Berube, P. M., and Stahl, D. A. (2012). The divergent AmoC3 subunit of ammonia monooxygenase functions as part of a stress response system in Nitrosomonas europaea. J. Bacteriol. 194, 3448-3456. doi: 10.1128/JB.00133-12

Bollmann, A., French, E., and Laanbroek, H. J. (2011). "Isolation, cultivation, and characterization of ammonia-oxidizing bacteria and archaea adapted to low ammonium concentrations," in Methods in Enzymology, ed. M. G. Klotz (San Diego, CA: Academic Press), 55-88. doi: 10.1016/B978-0-12-381294-0.00003-1

Bollmann, A., Sedlacek, C., Norton, J., Norton, J. M., Laanbroek, H. J., Suwa, Y., et al. (2013). Complete genome sequence of Nitrosomonas sp. Is79, an ammonia oxidizing bacterium adapted to low ammonium concentrations. Stand. Genom. Sci. 7, 469-482. doi: 10.4056/sigs.3517166

Campbell, M. A., Chain, P. S. G., Dang, H., Sheikh El, A. F., Norton, J. M., Ward, N. L., et al. (2011). Nitrosococcus watsonii sp. nov., a new species

\section{AUTHOR CONTRIBUTIONS}

JK and LS conceived the project; JK designed and performed all experiments, KK performed a PhyloPhlAn analysis and created the phylogenetic tree; JK, KK, and LS analyzed the data, JK and LS wrote and edited the manuscript.

\section{FUNDING}

Support for this research was provided by Alberta Innovates Technology Futures (JK and KK) and by a Discovery Grant from the Natural Sciences and Engineering Research Council of Canada (LS).

\section{ACKNOWLEDGMENT}

The authors would like to thank Dr. Annette Bollmann at Miami University, Oxford $\mathrm{OH}$ for providing cultures of Nitrosomonas sp. Is79A3.

\section{SUPPLEMENTARY MATERIAL}

The Supplementary Material for this article can be found online at: http://journal.frontiersin.org/article/10.3389/fmicb. 2016.01090

of marine obligate ammonia-oxidizing bacteria that is not omnipresent in the world's oceans: calls to validate the names 'Nitrosococcus halophilus' and “Nitrosomonas mobilis.” FEMS Microbiol. Ecol. 76, 39-48. doi: 10.1111/j.15746941.2010.01027.x

Cantera, J. J. L., and Stein, L. Y. (2007). Role of nitrite reductase in the ammoniaoxidizing pathway of Nitrosomonas europaea. Arch. Microbiol. 188, 349-354. doi: 10.1007/s00203-007-0255-4

Chain, P., Lamerdin, J., Larimer, F., Regala, W., Lao, V., Land, M., et al. (2003). Complete genome sequence of the ammonia-oxidizing bacterium and obligate chemolithoautotroph Nitrosomonas europaea. J. Bacteriol. 185, 2759-2773. doi: 10.1128/JB.185.9.2759-2773.2003

Dundee, L., and Hopkins, D. W. (2001). Different sensitivities to oxygen of nitrous oxide production by Nitrosomonas europaea and Nitrosolobus multiformis. Soil Biol. Biochem. 33, 1563-1565. doi: 10.1016/S0038-0717(01) 00059-1

Elmore, B. O., Bergmann, D. J., Klotz, M. G., and Hooper, A. B. (2007). Cytochromes P460 and c'-beta; A new family of high-spin cytochromes c. FEBS Lett. 581, 911-916. doi: 10.1016/j.febslet.2007.01.068

Garcia, J. C., Urakawa, H., Le, V. Q., Stein, L. Y., Klotz, M. G., and Nielsen, J. L. (2013). Draft genome sequence of Nitrosospira sp. Strain APG3, a psychrotolerant ammonia-oxidizing bacterium isolated from sandy lake sediment. Genome Announc. 1, e00930-13. doi: 10.1128/genomeA. 00930-13

Guindon, S., Dufayard, J.-F., Lefort, V., Anisimova, M., Hordijk, W., and Gascuel, O. (2010). New algorithms and methods to estimate maximumlikelihood phylogenies: assessing the performance of PhyML 3.0. Syst. Biol. 59, 307-321. doi: 10.1093/sysbio/syq010

Hollibaugh, J. T., Gifford, S., Sharma, S., Bano, N., and Moran, M. A. (2011). Metatranscriptomic analysis of ammonia-oxidizing organisms in an estuarine bacterioplankton assemblage. ISME J. 5, 866-878. doi: 10.1038/ismej.2010.172

Hommes, N. G., Sayavedra-Soto, L. A., and Arp, D. J. (2002). The roles of the three gene copies encoding hydroxylamine oxidoreductase in Nitrosomonas europaea. Arch. Microbiol. 178, 471-476. doi: 10.1007/s00203-002-0477-4 
Hooper, A. B., and Terry, K. R. (1979). Hydroxylamine oxidoreductase of Nitrosomonas: production of nitric oxide from hydroxylamine. Biochim. Biophys. Acta 571, 12-20. doi: 10.1016/0005-2744(79)90220-1

Jia, Z., and Conrad, R. (2009). Bacteria rather than Archaea dominate microbial ammonia oxidation in an agricultural soil. Environ. Microbiol. 11, 1658-1671. doi: 10.1111/j.1462-2920.2009.01891.x

Jones, L. C., Peters, B., Pacheco, J. S. L., Casciotti, K. L., and Fendorf, S. (2015). Stable isotopes and iron oxide mineral products as markers of chemodenitrification. Environ. Sci. Technol. 49, 3444-3452. doi: $10.1021 /$ es504862x

Ke, X., Lu, W., and Conrad, R. (2015). High oxygen concentration increases the abundance and activity of bacterial rather than archaeal nitrifiers in rice field soil. Microb. Ecol. 70, 961-970. doi: 10.1007/s00248-015-0633-4

Kester, R. A., De Boer, W., and Laanbroek, H. J. (1997). Production of NO and $\mathrm{N}_{2} \mathrm{O}$ by pure cultures of nitrifying and denitrifying bacteria during changes in aeration. Appl. Environ. Microbiol. 63, 3872-3877.

Klotz, M. G., Arp, D. J., Chain, P. S. G., El-Sheikh, A. F., Hauser, L. J., Hommes, N. G., et al. (2006). Complete genome sequence of the marine, chemolithoautotrophic, ammonia-oxidizing bacterium Nitrosococcus oceani ATCC 19707. Appl. Environ. Microbiol. 72, 6299-6315. doi: 10.1128/AEM. 00463-06

Klotz, M. G., and Stein, L. Y. (2011). "Genomics of ammonia-oxidizing bacteria and insights to their evolution," in Nitrification, eds B. B. Ward, D. J. Arp, and M. G. Klotz (Washington, DC: ASM Press), 57-93.

Kool, D. M., Dolfing, J., Wrage, N., and Van Groenigen, J. W. (2011). Nitrifier denitrification as a distinct and significant source of nitrous oxide from soil. Soil Biol. Biochem. 43, 174-178. doi: 10.1016/j.soilbio.2010.09.030

Kozlowski, J. A., Kits, K. D., and Stein, L. Y. (2016a). Complete genome sequence of Nitrosomonas ureae Strain Nm10, an oligotrophic group 6a Nitrosomonad. Genome Announc. 4:e00094-16.

Kozlowski, J. A., Kits, K. D., and Stein, L. Y. (2016b). Genome sequence of Nitrosomonas communis Strain Nm2, a mesophilic ammonia-oxidizing bacterium isolated from mediterranean soil. Genome Announc. 4, e1541-e1515. doi: 10.1128/genomeA.01541-15

Kozlowski, J. A., Price, J., and Stein, L. Y. (2014). Revision of N2O-producing pathways in the ammonia-oxidizing bacterium. Nitrosomonas europaea ATCC 19718. Appl. Environ. Microbiol. 80, 4930-4935. doi: 10.1128/AEM.01061-14

Kozlowski, J. A., Stieglmeier, M., Schleper, C., Klotz, M. G., and Stein, L. Y. (2016c). Pathways and key intermediates required for obligate aerobic ammoniadependent chemolithotrophy in bacteria and Thaumarchaeota. ISME J. doi: 10.1038/ismej.2016.2 [Epub ahead of print].

Krümmel, A., and Harms, H. (1982). Effect of organic matter on growth and cell yield of ammonia-oxidizing bacteria. Arch. Microbiol. 133, 50-54. doi: 10.1007/BF00943769

Law, Y., Ye, L., Pan, Y., and Yuan, Z. (2012). Nitrous oxide emissions from wastewater treatment processes. Philos. Trans. R. Soc. Lond. B. Biol. Sci. 367, 1265-1277. doi: 10.1098/rstb.2011.0317

Martens-Habbena, W., Berube, P. M., Urakawa, H., de la Torre, J. R., and Stahl, D. A. (2009). Ammonia oxidation kinetics determine niche separation of nitrifying Archaea and Bacteria. Nature 461, 976-979. doi: 10.1038/nature 08465

Martens-Habbena, W., Qin, W., Horak, R. E. A., Urakawa, H., Schauer, A. J., Moffett, J. W., et al. (2015). The production of nitric oxide by marine ammonia-oxidizing archaea and inhibition of archaeal ammonia oxidation by a nitric oxide scavenger. Environ. Microbiol. 17, 2261-2274. doi: 10.1111/14622920.12677

Norton, J. M. (2011). "Diversity and environmental distribution of ammoniaoxidizing bacteria," in Nitrification, eds B. B. Ward, D. J. Arp, and M. G. Klotz (Washington, DC: ASM Press), 39-56. doi: 10.1128/9781555817145

Norton, J. M., Klotz, M. G., Stein, L. Y., Arp, D. J., Bottomley, P. J., Chain, P. S. G., et al. (2008). Complete genome sequence of Nitrosospira multiformis, an ammonia-oxidizing bacterium from the soil environment. Appl. Environ. Microbiol. 74, 3559-3572. doi: 10.1128/AEM.02722-07

Poth, M., and Focht, D. D. (1985). $15 \mathrm{~N}$ kinetic analysis of $\mathrm{N}_{2} \mathrm{O}$ production by Nitrosomonas europaea: an examination of nitrifier denitrification. Appl. Environ. Microbiol. 49, 1134-1141.

Prosser, J. I., Head, I. M., and Stein, L. Y. (2014). “The family nitrosomonadaceae," in The Prokaryotes, eds M. Dworkinm, S. Falkow, E. Rosenberg, K.-H. Schleifer, and E. Stackebrandt (Berlin: Springer), 901-918.
Radax, R., Rattei, T., Lanzen, A., Bayer, C., Rapp, H. T., Urich, T., et al. (2012). Metatranscriptomics of the marine sponge Geodia barretti: tackling phylogeny and function of its microbial community. Environ. Microbiol. 14, 1308-1324. doi: 10.1111/j.1462-2920.2012.02714.x

Sayavedra-Soto, L. A., and Arp, D. J. (2011). “Ammonia-oxidizing bacteria: their biochemistry and molecular biology," in Nitrification, eds B. B. Ward, D. J. Arp, and M. G. Klotz (Washington, DC: ASM Press), 11-38.

Segata, N., Börnigen, D., Morgan, X. C., and Huttenhower, C. (2013). PhyloPhlAn is a new method for improved phylogenetic and taxonomic placement of microbes. Nat. Commun. 4:2304. doi: 10.1038/ncomms3304

Shaw, L. J., Nicol, G. W., Smith, Z., Fear, J., Prosser, J. I., and Baggs, E. M. (2006). Nitrosospira spp. can produce nitrous oxide via a nitrifier denitrification pathway. Environ. Microbiol. 8, 214-222. doi: 10.1111/j.1462-2920.2005. 00882.x

Stahl, D. A., and de la Torre, J. R. (2012). Physiology and diversity of ammoniaoxidizing Archaea. Annu. Rev. Microbiol. 66, 83-101. doi: 10.1146/annurevmicro-092611-150128

Stein, L. Y. (2011). "Surveying $\mathrm{N}_{2} \mathrm{O}$-producing pathways in bacteria," in Methods in Enzymology, Vol. 486, ed. M. G. Klotz (San Diego, CA: Academic Press), 131-152.

Stein, L. Y., Arp, D. J., Berube, P. M., Chain, P. S. G., Hauser, L., Jetten, M. S. M., et al. (2007). Whole-genome analysis of the ammonia-oxidizing bacterium, Nitrosomonas eutropha C91: implications for niche adaptation. Environ. Microbiol. 9, 2993-3007. doi: 10.1111/j.1462-2920.2007.01409.x

Stein, L. Y., Sayavedra-Soto, L. A., Hommes, N. G., and Arp, D. J. (2000). Differential regulation of amoA and $\mathrm{amoB}$ gene copies in Nitrosomonas europaea. FEMS Microbiol. Lett. 192, 163-168. doi: 10.1111/j. 1574-6968.2000.tb09376.x

Stein, L. Y., and Yung, Y. L. (2003). Production, isotopic composition, and atmospheric fate of biologically produced nitrous oxide. Annu. Rev. Earth Planet. Sci. 31, 329-356. doi: 10.1146/annurev.earth.31.110502.080901

Suwa, Y., Yuichi, S., Norton, J. M., Bollmann, A., Klotz, M. G., Stein, L. Y., et al. (2011). Genome sequence of Nitrosomonas sp. strain AL212, an ammoniaoxidizing bacterium sensitive to high levels of ammonia. J. Bacteriol. 193, 5047-5048. doi: 10.1128/JB.05521-11

Urakawa, H., Garcia, J. C., Nielsen, J. L., Le, V. Q., Kozlowski, J. A., Stein, L. Y., et al. (2014). Nitrosospira lacus sp. nov., a psychrotolerant ammonia-oxidizing bacterium from sandy lake sediment. Int. J. Syst. Evol. Microbiol. 65, 242-250. doi: 10.1099/ijs.0.070789-0

Wrage, N., Velthof, G. L., Oenema, O., and Laanbroek, H. J. (2004). Acetylene and oxygen as inhibitors of nitrous oxide production in Nitrosomonas europaea and Nitrosospira briensis: a cautionary tale. FEMS Microbiol. Ecol. 47, 13-18. doi: 10.1016/S0168-6496(03)00220-4

Yu, R., and Chandran, K. (2010). Strategies of Nitrosomonas europaea 19718 to counter low dissolved oxygen and high nitrite concentrations. BMC Microbiol. 10:70. doi: 10.1186/1471-2180-10-70

Yu, R., Kampschreur, M. J., Loosdrecht, M. C. M. V., and Chandran, K. (2010). Mechanisms and specific directionality of autotrophic nitrous oxide and nitric oxide generation during transient anoxia. Environ. Sci. Technol. 44, 1313-1319. doi: 10.1021/es902794a

Zhu, X., Burger, M., Doane, T. A., and Horwath, W. R. (2013). Ammonia oxidation pathways and nitrifier denitrification are significant sources of $\mathrm{N}_{2} \mathrm{O}$ and $\mathrm{NO}$ under low oxygen availability. Proc. Natl. Acad. Sci. U.S.A. 110, 6328-6333. doi: 10.1073/pnas.1219993110

Zhu-Barker, X., Cavazos, A. R., Ostrom, N. E., Horwath, W. R., and Glass, J. B. (2015). The importance of abiotic reactions for nitrous oxide production. Biogeochemistry 126, 251-267. doi: 10.1007/s10533-0150166-4

Conflict of Interest Statement: The authors declare that the research was conducted in the absence of any commercial or financial relationships that could be construed as a potential conflict of interest.

Copyright $\odot 2016$ Kozlowski, Kits and Stein. This is an open-access article distributed under the terms of the Creative Commons Attribution License (CC BY). The use, distribution or reproduction in other forums is permitted, provided the original author(s) or licensor are credited and that the original publication in this journal is cited, in accordance with accepted academic practice. No use, distribution or reproduction is permitted which does not comply with these terms. 